Uniwersytet Marii Curie-Skłodowskiej w Lublinie

Wydział Humanistyczny

Instytut Filologii Słowiańskiej

tel.: +48 815372652

e-mail: pzlotko@poczta.umcs.lublin.pl

\title{
Nazwy młynów i osad młyńskich dawnego starostwa brańskiego
}

Słowa kluczowe: onomastyka, toponimia, nazwy młynów

Polska literatura onomastyczna nie doczekała się wielu opracowań z zakresu nazewnictwa młynów i osad młyńskich. Uwaga autorów dotychczasowych prac koncentrowała się zarówno na nazwach młynów, jak również na toponimach i mikrotoponimach zawierających komponent $\mathrm{w}$ postaci ap. młyn ${ }^{1}$. Jedną z pierwszych prób opracowania tego typu nazw był artykuł T. Gołębiowskiej, poddany następnie krytyce przez historyka J. Wiśniewskiego [Gołębiowska 1969; Wiśniewski 1970]. Wnioski autorki, wysunięte na podstawie analizy pokaźnej ilości zapisów wyekscerpowanych

1 Por. m.in.: Wołowik B., 1982, Nazwy toponimiczne zwiazane z podstawa mtyn, „Zeszyty Naukowe WSP w Opolu, Językoznawstwo", VIII, s. 37-54; Wołowik B., 1984, Nazwy toponimiczne zwiazane z podstawa folusz, „Zeszyty Naukowe WSP w Opolu, Językoznawstwo", IX, s. 131-137; Wołowik B., 1986, Nazwy toponimiczne zwiazane z mtynem wietrznym, [w:] Nazwy wtasne a wyrazy pospolite w języku i tekście, Opole, s. 251-268, Rymar E., Czopek B., 1993, Nazwy młynów i osad mtyńskich na terenie dawnej Nowej Marchii, „Onomastica Slavogermanica”, XVIII, s. 61-115; Chludziński A., 1998, Nazwy mtynów i osad młyńskich w byłym powiecie białogardzkim, „Rocznik Koszaliński”, XXVIII, 309-326; Rutkiewicz M., 2003, Nazewnictwo poznańskich młynów wodnych a współczesna onomastyka miasta, [w:] Metodologia badań onomastycznych, red. M. Biolik, Olsztyn, s. 580-591; Biolik M., 2011, Młyny wodne i wiatraki w nazwach obiektów terenowych na Warmii i Mazurach, „Prace Językoznawcze UWM”, XIII, s. 19-32. 
pracowicie ze Stownika geograficznego Królestwa Polskiego i innych krajów słowiańskich, okazały się niemiarodajne, gdyż nie uwzględniały aspektu historyczno-kulturowego. Sama badaczka musiała odczuwać bezradność, ponieważ przyznała, że nie jest w stanie dokonać pełnej analizy onomastycznej niektórych nazw z uwagi na brak dodatkowych poświadczeń [Gołębiowska 1969, 109]. Jednym z zarzutów postawionym T. Gołębiowskiej we wspomnianej recenzji było zaliczenie przez nią do grupy nazw topograficznych i kulturalnych dużej ilości onimów, które w istocie mogły być motywowane antroponimami określającymi młynarzy, bądź ich rodziny [Wiśniewski 1970, 452, 454].

Inspiracją do powstania niniejszego tekstu było stwierdzenie J. Wiśniewskiego: „Zaliczanie konkretnych nazw młynów do odpowiednich grup nazewniczych wymaga ustalenia pochodzenia każdej nazwy w oparciu o źródła historyczne lub o wyniki badań historyków osadnictwa ..." [Wiśniewski 1970, 455]. Z uwagi na to, iż teren starostwa brańskiego nie doczekał się do chwili obecnej dogłębnych studiów z zakresu historii osadnictwa, aby stworzyć podstawę do właściwej analizy onomastycznej, należało zebrać rozproszony materiał źródłowy. Na jego podstawie udało się odtworzyć dzieje każdego młyna i osady młyńskiej oraz zmiany demograficzno-własnościowe w nich zachodzące, oraz ustalić reprezentatywny zbiór poświadczeń źródłowych nazw.

Nie wszystkie zebrane w artykule onimy odnotowane są w monografii M. Kondratiuka o nazwach miejscowych Białostocczyzny [Kondratiuk 1974]. Brakuje w niej nazw 4 punktów osadniczych, oraz niektórych obocznych postaci pozostałych mian. W opracowaniu zweryfikowano również niektóre szczegółowe ustalenia M. Kondratiuka w zakresie lokalizacji osad i motywacji nazw.

Powstanie sieci regularnie rozmieszczonych młynów wodnych, w starostwie brańskim, położonym na terenie dawnego województwa podlaskiego, można z wielkim prawdopodobieństwem datować na XVI w., choć niewykluczone, że niektóre młyny mogły powstać nawet wcześniej. Pierwsze wiadomości o młynarzach, wraz z ich imionami, a niekiedy również nazwiskami. zawarte są w inwentarzu starostwa z 1558 r. Dopiero jednak w rejestrze pomiary włócznej z 1563 r. odnaleźć można dokładne informacje o rodzaju i lokalizacji młynów, wraz z należącymi do nich gruntami, oraz o ich użytkownikach. Wszystko wskazuje na to, że były to młyny przeznaczone do przemiału zboża, brak bowiem informacji o istniejących przy nich kuźnicach, papierniach, tartakach itp. Jedynymi śladami, wskazującym na możliwość innej niż przemiał zboża, działalności młynów, jest wiadomość o foluszu należącym w 1558 r. do Janka i Miska Burkatowi- 
czów oraz odnotowanie mieszkającego w 1846 r. przy młynie w Otapach folusznika².

Przeanalizujmy więc kolejno informacje o każdym z istniejących w dawnym starostwie brańskim młynów i wyodrębnionych przy nich osadach młyńskich. Postarajmy się ustalić motywację poszczególnych nazw oraz prześledźmy ich zmiany na przestrzeni wieków, jeśli takowe zachodziły. Zwróćmy przy tym uwagę na czynniki mogące mieć wpływ na akt nominacji.

Młyn w Brańsku. Młyn pod miastem Brańskiem na Nurcu znajdował się w $1563 \mathrm{r}$. w posiadaniu potomstwa nieżyjącego Borkowskiego ${ }^{3}$. Innym znanym z imienia i nazwiska właścicielem młyna w tym mieście był Jan Hieronim Brzozowski odnotowany w źródłach w 1635 r. ${ }^{4}$ Lustracja z 1667 r. poświadcza istnienie młyna $\mathrm{w}$ Brańsku, nie wymienia natomiast jego posiadacza. Możliwe, że śladem po istnieniu młyna miejskiego jest ulica Młyńska w Brańsku, znana już w XVI w. Przykładowo, siedlisko przy niej położone, miał w 1563 r. m.in. Jan Borzymowski, posesor młyna przy folwarku kiersnowskim, natomiast w 1680 r. mieszkał na tejże ulicy Młynarz wraz z zięciem.

Abramiki. Obecna osada Abramiki stanowi część wsi Bujnowo [UN 33; WUN 2]. Wieś powstała w II poł. XVII w. na terenie dawnego zaścianka Szpakowszczyzna, którego nazwa motywowana jest n. os. Szpak [SHNOB II 131]. Współcześnie mianem tym określane jest pole we wsiach Bujnowo i Malesze, położone przy granicy tych miejscowości [UN 34, 35]. W I poł. XVI w. znajdowały się tu siedziby bojarów Szpaków, których w czasie pomiary włócznej przeniesiono na miejsce dzisiejszej wsi Szpaki ${ }^{5}$. Opustoszały teren był w 1565 r. w posiadaniu Franciszka Zubrzyckiego, zaś w 1598 r. jego właścicielem był Abraham Chodkowicz, bojar ze Szpak ${ }^{6}$. Najprawdopodobniej to od jego imienia pochodzi nazwa wsi. Możliwe jest tė̇, że onim został urobiony od im. młynarza Abrahama Mikity ze Szpak (Szpakowszczyzny). Niewykluczone, że obie osoby są tożsame. Pod koniec XVIII w., jako że wieś nie była wspomniana w rejestrze pomiary włócznej starostwa brańskiego z 1563 r., wyrokiem sądu Referendarii Koronnej zdecydowano o przeniesieniu osady na grunty pobliskiej wsi Malesze ${ }^{7}$. Postanowienia tego jednak nigdy nie zrealizowano. Nazwa Abramiki, dawniej

\footnotetext{
2 AVAK XIV, s. 27; Br III/S/1, k. 32.

3 PKGE II, s. 406.

4 MK 180, k. 470 v. -471.

5 PKGE II, s. 374.

6 M 1708-1-82, k. 47 v. -48.

7 Ks. Ref. 58, k. 226 v. -227.
} 
Abrahamiki jest nazwą rodową motywowaną hebr. im. Abraham $>$ Abram [Tichoniuk 1988, 12].

Burchaty. Wieś powstała na terenie zaścianka młynarskiego, położonego nad rzekami Czarną i Lichczą, będącego w 1563 r. w posiadaniu Jana Burkata $^{8}$ [WUN 214]. Inwentarz starostwa brańskiego z 1558 r., odnotowuje dwóch Janków, dwóch Szymonów oraz Miska Burkatowiczów ${ }^{9}$. Pierwszy, nie do końca pewny, zapis nazwy rodowej Burkaty, motywowanej nazwiskiem rodu młynarskiego, należy odnieść do 1599 r. ${ }^{10} \mathrm{~W}$ podstawie toponimu leży pochodna postać Burkat germ. im. Burghard [Malec 1994, 202]. Do zmiany rdzennej spółgłoski tylnojęzykowej, ze zwartej na szczelinową $(x<k)$, doszło zapewne w XVIII w., gdyż jeszcze w XVII w. konsekwentnie zapisywano nazwę wsi jako Burkaty. Nazwisko Burkat utrzymało się w osadzie do poł. XVII w., a w sąsiednich wsiach nawet dłużej. Wiele wskazuje na to, że miano Burkat w nazwiskach mieszkańców tej osady, zostało zastąpione innymi antroponimami.

Jarmarkowszczyzna. Osada, będąca współcześnie kolonią wsi Bronka, położona nad rzeką o tej samej nazwie [UN 14; WUN 710]. Jak podaje rejestr pomiary włócznej starostwa brańskiego, w 1563 r., w miejscu obecnego punktu osadniczego, znajdował się młyn Jermaka Rojewicza'11. Nazwa miejscowości ma postać dzierżawczą i jest motywowana wsł. im. Jarmak > cerk. Jermotaj < gr. Hermolaos [Tichoniuk 2000, 95]. Inny przedstawiciel rodu Rojewiczów o imieniu Choczko, stracił swój młyn w wyniku pomiary włócznej i został osadzony w sąsiedniej wsi Załuskie (dawniej Załozie) ${ }^{12}$. Obecna postać nazwy, zdaniem M. Kondratiuka, powstała przez adideację do ap. jarmark [Kondratiuk 1974, 76]. Pomimo, że wariant Jarmarkowszczyzna pojawia dość wcześnie, bo już w 1599 r., jeszcze przez cały XVII w., obie postacie nazwy (Jarmakowszczyzna/Jarmarkowszczyzna) używane były wymiennie. Potomków Jermaka Rojewicza w linii męskiej, zastąpił w tej osadzie ród Radziwonów, którego protoplastą był Radziwon Wasiuczyk, młynarz pochodzący z nieodległej wsi młyńskiej Puchacze. Ród Radziwonów przyjął następnie nazwisko Czarniawski. Zamieszkiwał on Jarmarkowszczyznę aż do czasów współczesnych.

Krupki. Obecnie nazwa ta określa las i pole w granicach administracyjnych miasta Brańsk [UN 13; SNT 221]. W poł. XVI w. istniał tu młyn

\footnotetext{
8 PKGE II, s. 409.

9 AVAK XIV, s. 27.

10 Ks. Ref. 2, k. 12 v.

11 PKGE II, s. 408.

12 PKGE II, s. 362.
} 
położony nad strumieniem Borbek (obecnie Panasówka), którego posesorem był Sieńko Decewicz Krupka ${ }^{13}$. Nazwa młyna i przyległego do niego obszaru, a obecnie lasu i pola, pochodzi od n. os. Krupka, określającej tenże ród młynarski i ma postać nazwy rodowej. W XVII w. młyn wyszedł z posiadania rodziny Krupków, a pretensje do niego rościli proboszczowie brańscy. Sprawa praw własności do młyna była rozstrzygana w $1778 \mathrm{r}$. Wyrokiem sądu Referendarii Koronnej młyn Krupki przysądzono Łukaszowi Czerniawskiemu, z warunkiem zadośćuczynienia pieniężnego poprzednim nieprawnym właścicielom ${ }^{14}$. Na podstawie zachowanych źródeł trudno jednoznacznie stwierdzić, czy młyn rzeczywiście funkcjonował w XVII i XVIII w., czy tylko na potrzeby procesu używano określenia mtyn na gruncie Krupki albo mtyna niegdy Krupki zwanego. Punktu osadniczego Krupki nie odnotowuje żadne ze znanych źródeł z okresu XVI-XVIII w., a więc najprawdopodobniej nie wytworzyła się tu żadna osada.

Kumat. Współcześnie nazwą tą określane jest bagno i pastwisko we wsi Kalnica, łąka we wsi Kiersnówek, łąka i pole w mieście Brańsk oraz most we wsi Kiersnówek (Most na Kumacie) [UN 15; SNT 231]. Wszystkie wymienione obiekty położone są na terenie dawnego uroczyska noszącego tą nazwę. Dawne poświadczenia nazwy odnoszą się do 1679 i 1784 r., a więc była ona znana co najmniej od XVII w. ${ }^{15}$ Miejscowa tradycja ukazuje obiekt jako miejsce starcia wojsk mazowieckich z jaćwieskimi w 1264 r. oraz mogiłę wodza jaćwieskiego Kumata. Ostanie badania onomastyczno-historyczne stawiają pod znakiem zapytania utrwaloną w tradycji lokalizację owych wydarzeń [Złotkowski 2014]. Okazuje się bowiem, że na tym terenie w XVI w. funkcjonował młyn Iwana Żeguni Tuszewickiego, który wedle wszelkiego prawdopodobieństwa przestał istnieć na przełomie XVI i XVII w. ${ }^{16} \mathrm{Na}-$ zwa Kumat nawiązuje do imienia Konrad, które nosił syn owego Iwana Żeguni. W związku ze wspomnianą legendą zakorzenił się w literaturze onomastycznej pogląd o bałtyjskiej genezie nazwy. W rzeczywistości jest to onim, pochodzący od postaci Kunat germ. im. Konrad, z wymianą samogłoski nosowej $m<n$ [Malec 1994, 262]. Występowanie im. Komat/Kumat na tym terenie w XVI-XVII w. jest poświadczone źródłowo. Udało się również ustalić dawną nazwę uroczyska, która miała postać Rybakowszczyzna. Jest to nazwa dzierżawcza, motywowana najprawdopodobniej n. os. Ry$b a k$ [SHNOB II 76].

\footnotetext{
13 PKGE II, s. 407.

14 Ks. Ref. 31, k. 129-136 v.

15 M 1708-1-174, k. 623 v.; KRB, k. 193.

16 PKGE II, s. 407.
} 
Majorowizna. Obecnie jest to kolonia wsi Kiersnówek [UN 15; WUN 1204]. Początkiem osady był młyn na rzece Nurcu, który w 1563 r. był w posiadaniu Kiersnowskiego ${ }^{17}$. W rękach tejże rodziny, o przydomku Daszkiewicz, pozostawał do lat 60-tych XVII w. Pierwotna nazwa młyna, Kiersnowski, o charakterze syngulatywnym, nawiązywała do nazwiska jego posiadaczy. Kolejne miano Daszkowszczyzna, mające charakter dzierżawczy, motywowane była przydomkiem szlacheckiej (dawniej bojarskiej) rodziny Kiersnowskich. B. Tichoniuk łączy wsł. deminutywną formę Dasz z podstawą w postaci gr. im. Dasjusz, M. Malec wywodzi ją natomiast od hebr. im. Daniel [Tichoniuk 2000, 80; Malec 1994, 207]. Około 1663 r. młyn otrzymał za zasługi poniesione dla Rzeczpospolitej major Jan Żelski18. Obecna dzierżawcza nazwa osady została urobiona, od ap. określającego range (stopień wojskowy) wspomnianego posesora młyna.

Nełchy. Nieistniejąca już osada młyńska Nełchy rozwinęła się najprawdopodobniej przy młynie, położonym nad rzeką Nurcem, będącym w $1563 \mathrm{r}$. w posiadaniu Jarosza Niestrowicza ${ }^{19}$. W 1608 r. pojawia się w źródłach rodowa nazwa tej osady w postaci Mielechy, motywowana wsł. im. ${ }^{*}$ Melech, Mielech > Melecjusz, Emilian ${ }^{20}$. [Tichoniuk 2000, 84]. Analizowany toponim ewoluował następnie do postaci Nełchy, poprzez wymianę nagłosowej spółgłoski nosowej $m<n$, oraz zanik samogłoski rdzennej $e$. Sprawę komplikuje dodatkowo fakt istnienia, co najmniej od lat 60-tych do 80-tych XVII w., dwóch młynów o nazwach Nełchy (Nielchy) i Mielechy. Pierwszy z nich trzymali młynarze Wawrzyniec Kumat, Łukasz i Stefan Sierhiejowice oraz Wawrzyniec Dziki, drugi zaś był własnością młynarza Wawrzyńca Stasił$\mathrm{ka}^{21}$. Dokładna analiza zapisów źródłowych utwiedza nas w przekonaniu, że w obu młynach zamieszkiwali, jeśli nie w całości to w większości, członkowie rodziny młynarskiej, która stopniowo przyjmowała nazwisko Kunicki. Młyn Mielechy najprawdopodobniej przestał istnieć pod koniec XVII w. W związku z nim pozostaje niewątpliwie mikrotoponim (nazwa łąki) $\mathrm{Me}$ lechowszczyzna, poświadczony we wsi Chojewo w 1782 r. ${ }^{22}$ Osada Nełchy istniała jeszcze w I poł. XIX. W II poł. XVIII w. przyjęła się jeszcze jej druga nazwa w postaci Kunicki, motywowana nazwiskiem rodziny posiadającej młyn.

17 PKGE II, s. 407.

18 M 1708-1-43, k. 484-484v.

19 PKGE II, s. 409.

20 M 1708-1-98, k. 690 v.

21 AR XXV 361, k. 5

22 Ks. Ref. 58, k. 229. 
Onacki. Współcześnie nazwa Onaczki określa pole w miejscowości Torule [SNT 331]. Istnieje również rów Onaczkowski w tejże wsi [UN 32]. Dawna osada Onacki już nie istnieje. Zanikła najprawdopodobniej w XIX w. Rejestr pomiary włócznej starostwa brańskiego z 1563 r. odnotowuje młyn na rzece Lichczy w uroczysku Boczkowicze (w źródle Raczkowiczi), który użytkowali Jewłasz Żegunia i Iwan Maleszow ${ }^{23}$. Pierwotna nazwa uroczyska, a potem osady Boczkowicze, miała charakter patronimiczny. Nie ulega wątpliwości, że toponim został urobiony od imienia młynarza Onacka Boczkowicza, występującego w źródle z 1599 r. ${ }^{24}$ Wydaje się, że pierwotnie nazwa młyna, miała postać Onacko (N. sg.), jednak już w XVII w. utrwaliła się nazwa rodowa osady w postaci Onacki. Ojkonim motywowany jest wsł. postacią genetycznie hebr. im. Jonatan (cerk. Ionafan). Niekiedy antroponim Onacko/Onackowicz był notowany łącznie z nazwiskiem Tuszewicki, co może sugerować, że rodzina Onacków wyodrębniła się z rodu Tuszewickich. Jest to dość prawdopodobne, zważywszy na to, że obie osady (Onacki i Żegunie - prawdopodobne gniazdo Żeguniów Tuszewickich), sąsiadują ze sobą. Wieś zanikła najprawdopodobniej na przełomie XIX i XX w.

Otapy. Obecnie jest to kolonia wsi Kiersnówek [WUN 1515]. M. Kondratiuk, w swojej monografii o nazwach miejscowych Białostocczyzny, traktuje ją jako osadę nieistniejącą [Kondratiuk 1974, 150]. Wg danych z 1972 r. nazwa ta określa pole we wsi Kiersnówek [UN 15]. W 1563 r. młyn nad rzeką Nurzec, wraz z zaściankiem, znajdował się w posiadaniu Jana Borzymowskiego. Pierwotna nazwa osady, w postaci młyn Borzymowski, została więc utworzona od nazwiska właściciela młyna, metodą transonimizacji ${ }^{25}$. W 1632 r. Feliks Augustynik przekazał prawa do młyna Borzymowski Wojciechowi i Bartłomiejowi Augustynikom² ${ }^{26}$ W poł. XVII w. młyn ten posiada również nazwę Szczęsny/Szczęsnowski, urobioną niewątpliwie od imienia owego Feliksa Augustynika. Nazwa ta nie utrzymała się długo, bowiem już w 1691 r., pojawiło się funkcjonujące współcześnie miano tego miejsca ${ }^{27}$. Obecna nazwa rodowa osady motywowana jest nazwiskiem rodu młynarskiego Otapów, poświadczonym w źródłach historycznych już w 1647 i 1650 r., który w XVIII w. przyjął nazwisko Dąbrowski28. Istnieją dwie przesłanki

\footnotetext{
23 PKGE II, s. 410.

24 MK 143, k. 186.

25 PKGE II, s. 406.

26 RA Enskilda 8636, k. 139v-140v.

27 M 1708-1-192, k. 192

$28 \mathrm{Br} \mathrm{I} / \mathrm{B} / 1, \mathrm{~m}$. in. 1647 i $1650 \mathrm{r}$.
} 
zmiany nazwy młyna. Możliwe jest, że rodzina Augustyników posiadała dodatkowe określenie w postaci n. os. Otap, albo młyn w II poł. w stał się własnością rodu Otapów. Trudno, przy obecnym stanie wiedzy, jednoznacznie rozstrzygnąć tę kwestię, jednak druga możliwość wydaje się bardziej prawdopodobna.

Pace. Istniejąca obecnie wieś, ukształtowała się przy młynie, położonym nad rzeką Nurzec, którego posiadaczem był w 1563 r. Pac Romanowicz $^{29}$ [WUN 1521]. Jego potomstwo najwidoczniej posługiwało się patronimicznym określeniem Pacewicze, bowiem w 1599 r. odnotowany jest młynarz Leonard Paciewic (Paczewic), właściciel dwóch młynów w starostwie brańskim, nad rzeką Nurcem ${ }^{30}$. Nazwa rodowa osady w postaci Pace (Pacze) została po raz pierwszy odnotowana w źródłach w 1630 r. i utrzymała się w tej postaci do dnia dzisiejszego ${ }^{31}$. Motywacją tej nazwy jest derywat sufiksalny Pac $(z)<$ im. Pawet lub im. Hipacjusz (Hipacy) gr. Hypatos, cerk. Ipatij [Malec 1994, 304; Tichoniuk 2000, 96].

Puchacze. Obecnie jest to część wsi Bujnowo, leżąca nad rzeką Bronką [UN 33; WUN 1803]. Zaczątkiem dzisiejszej osady był młyn Waśki Puchacza, wymieniony w rejestrze pomiary włócznej starostwa brańskiego ${ }^{32}$. Nazwa rodowa miejscowości nawiązuje do nazwiska, motywowanego ap. puchacz, rodziny młynarskiej założycieli wsi [SEMot 243]. Mimo, iż po raz pierwszy poświadczona jest w 1618 r., musiała ukształtować się już wcześniej33. Ród młynarzy Puchaczów jest odnotowany, jako mieszkający w tej osadzie, w źródle z końca XVII w. ${ }^{34}$ W XVIII występowało tu nazwisko Acz/Aczewicz/Haciuk, kontynuowane współcześnie w postaci Gać/Hać. Współczesne nazwisko może być przekształceniem pierwotnego miana rodowego, a powstało zapewne poprzez ucięcie elementu nagłosowego.

Solniki. Istniejąca obecnie wieś Solniki rozwinęła się przy młynie na rzece Lichczy, który 1563 r. posiadali Wojtek, Paweł wraz z braćmi Solnikowie $^{35}$ [WUN 2018]. Przedstawiciele rodu młynarskiego Solników są dość dobrze poświadczeni w zachowanych źródłach z XVI-XVII w. Nazwa rodowa Solniki, motywowana n. os. Solnik < ap. solnik 'zajmujący się wydobyciem soli, solarz', określała młynarzy zamieszkałych w tej osadzie.

\footnotetext{
29 PKGE II, s. 409.

30 MK143, k. 194 v. -195.

31 M 1708-1-206, k. 484 v.

32 PKGE II, s. 408.

33 M 1708-1-31, k. 635

34 KGB 52, k. 202

35 PKGE II, s. 411.
} 
[SHNOB II 106]. Jest poświadczona jako nazwa młyna już w 1563 r., natomiast jako nazwa osady najprawdopodobniej w 1599 r. ${ }^{36}$

Torule. Zaczątek współczesnej wsi stanowił młyn istniejący już w 1563 r., położony nad rzeką Czarną, który trzymali Matys, Paweł i Piotr Turulowie $^{37}$ [WUN 2228]. Nazwisko Turula, wedle obecnego stanu wiedzy, jest odnotowane jeszcze w $1653 \mathrm{r}$. i $1755 \mathrm{r} .{ }^{38} \mathrm{~W}$ zapisach z XVIII i I poł. XIX w. wśród mieszkańców osady, zdecydowanie przeważa nazwisko Ryszkowski. Analizowany toponim pochodzi od nazwiska, mającego prawdopodobną genezę bałtyjską, młynarzy Turula ${ }^{39}$. Wydaje się, że ustalił się on dość wcześnie, bo już w poł. XVI w., najpierw jako nazwa młyna, potem jako miano osady młyńskiej, co potwierdzają poświadczenia źródłowe.

Wilginie. Obecnie nazwą tą określa się część wsi Wojtki [UN 33]. Osada Wilgnie rozwinęła się przy młynie nad rzeką Czarną, który wedle źródła z 1563 r., znajdował się w posiadaniu Szymona Wilkinia ${ }^{40}$. Nazwa rodowa osady powstała od nazwiska młynarzy Turula. Według M. Kondratiuka nazwisko to jest zeslawizowaną formą litewskiej n. os. Vilkinis : Wilkas, motywowaną ap. wilk, z mazowiecką wymianą spółgłoski $k<g$ [Kondratiuk 1985, 78]. Pierwotne zapisy nazwy poświadczają występowanie rdzennej spółgłoski $k$. Można zastanowić się, czy aby na pewno mamy do czynienia z wpływem bałtyjskim na powstanie tego antroponimu. Niewykluczona jest też geneza słowiańska, bo np. w staropolskim materiale antroponimicznym odnaleźć można przykładową n. os. Wilkan, utworzoną od ap. wilk [SEMot 342]. Nazwa rodowa osady poświadczona jest po raz pierwszy w postaci Wilkinie w 1635 r. ${ }^{41}$ Nazwisko Wilkinia/Wilginia było natomiast notowane w osadach młynarskich starostwa brańskiego oraz w mieście Brańsku w okresie od XVI do XVIII w. Wieś istniała jeszcze w poł. XIX w., lecz niedługo potem zanikła.

Wojtki. Zalążkiem dzisiejszej wsi był młyn Szczęsnego Siedleckiego, położony nad rzeką Czarną, odnotowany w źródle z 1563 r. ${ }^{42}$ [WUN 2375].

\footnotetext{
36 PKGE II, s. 411; M 1708-1-96, k. 264 v.

37 PKGE II, s. 410.

38 Br I/B/1 r. 1653; Bk I/B/4 r. 1755.

39 M. Kondratiuk widzi w zapisie n. os. młynarza z tej miejscowości Piotr Turulionic, bałt. antroponim Turulionis, a niewykluczone, że może tu chodzić o zniekształcony zapis formacji patronimicznej Turulowic. Należałoby się więc zastanowić, czy ta n. os. nie jest motywowana słowiańską podstawą apelatywną tur i formantem -ul(a), produktywnym w antroponimii słowiańskiej [por. Kondratiuk 1985, 76].

40 PKGE II, s. 410.

41 MK 181, k. 122

42 PKGE II, s. 410.
} 
Ów młynarz był nazywany również Szczęchem Wojtkowiczem. To właśnie ten antroponim o charakterze patronimicznym, motywowany słow. im. Wojciech, legł u podstaw pierwotnej nazwy osady, w formie Wojtkowic(z)e. Najstarszy zapis onimu w postaci pochodzi z $1601 \mathrm{r} .{ }^{43}$ Nazwa miejscowa przeszła z kategorii nazw patronimicznych do nazw rodowych dopiero w XVIII w. i w tej postaci jest używana konsekwentnie do dnia dzisiejszego.

Wysockie. Początkiem, nieistniejącej obecnie osady, był młyn o nazwie Surojeska, nad rzeką Lichczą, który w 1563 r. znajdował się w posiadaniu Jurka, Sacza i Szymka Surojeskowiczów ${ }^{44}$. Pierwotna nazwa nawiązuje do nieprzejrzystego semantycznie antroponimu Surojeska. Nazwa osady młyńskiej Wysocki pojawia się po raz pierwszy w lustracji starostwa brańskiego z lat 1661-166445. Należy chyba przyjąć, że toponim ten powstał metodą transonimizacji od antroponimu Wysocki. Nazwisko Wysocki jest, co prawda, poświadczone źródłowo w tej osadzie, po raz pierwszy dopiero w latach 80-tych XVII w., niewykluczone jednak, że mogło istnieć tu już wcześniej46. Dość wcześnie, bo już w XVII w. toponim przybiera postać nazwy rodowej. Wieś zanikła pod koniec XVIII w.

Żegunie. Osada o tej nazwie obecnie nie istnieje, jednak mikrotoponim Żegunie notowany jest na terenie wsi Wojtki (pastwisko, pole) [SNT 604]. Według danych z 1972 r. nazwa ta miała określać część wsi Solniki [UN 32]. Zaczątkiem wsi był młyn położony nad rzeką Lichczą, który zgodnie z opisem zawartym w rejestrze pomiary włócznej starostwa brańskiego z 1563 r., użytkował Klimko Malosicz ${ }^{47}$. Nazwa rodowa osady musiała wytworzyć się dość wcześnie, gdyż już w tymże roku określa się zaścianek młynarski jako Żegunie Sraki. Pierwszy antroponim, ma zdaniem M. Kondratiuka, genezę bałtyjską. Warto jednak zastanowić się, czy aby nie powstał od psł. rdzenia * žekti, * žbga 'palić'48. Nawiązuje on do określenia rodu młynarskiego Żeguniów Tuszewickich, którego przedstawiciele, już w XVI w., odnotowani są w co najmniej 4 młynach (osadach młyńskich) starostwa brańskiego. Jednemu z przedstawicieli tej rodziny udało się nawet przeniknąć w XVII w. w szeregi szlachty [Złotkowski 2014, 244]. Drugie określenie zaścianka młynarskiego motywowane jest n. os. Sraka, którą można łączyć z psł. leksemem * ssrati,

\footnotetext{
43 M 1708-1-91, k. 442 v.

44 PKGE II, s. 409.

45 AR XXV 361, k. 6

$46 \mathrm{Br} \mathrm{I} / \mathrm{B} / 1$ r. 1689.

47 PKGE II, s. 411.

48 Nazwy Żeguta, Żegan, por. SEMot 374.
} 
stanowiącym zapewne dodatkowy przydomek rodu Żeguniów49. Niewykluczone jednak, że było to tylko zbiorowe określenie młynarzy, dzierżących ten młyn, które nigdy nie przeszło do płaszczyzny toponimicznej. Osada zanikła najprawdopodobniej w XIX w.

Z przytoczonych wyżej informacji wynika iż, w okresie od XVI w. do czasów nam współczesnych, na badanym obszarze, znacznie zmniejszania się ilości osad o genezie młyńskiej. W $1563 \mathrm{r}$. funkcjonowało 17 młynów (w tym obiekt w mieście Brańsku), obecnie istnieje tylko 10 osad, których zalążkiem był dawny młyn. Jednocześnie w tym czasie powstały tylko dwa nowe młyny. Bez wątpienia wpływ na to miała pogarszająca się koniunktura gospodarcza oraz wyniszczające wojny, szczególnie te z poł. XVII w. Zanikłe osady pozostawiły po sobie ślad w postaci mikrotoponimów, a tylko dwie (Nełchy, Wysockie) nie utrwaliły się w zbiorowej pamięci mieszkańców.

W zgromadzonym materiale nazewniczym odnotować należy występowanie posesywnych struktur typu młyn Jana Borzymowskiego, które nie są nazwami własnymi we właściwym znaczeniu tego słowa, lecz deskrypcjami. Umieszczono je w zbiorze poświadczeń źródłowych, z uwagi na to, iż mogły okazać się pomocne w prawidłowej identyfikacji onimów i ich denotatów. Odrębną grupą, lecz niewątpliwie powiązaną z nazwami stanowiącymi przedmiot naszych rozważań, są nazwy terenowe, określające miejsca w których powstawały młyny, jak np. Szpakowszczyzna, Rybakowszczyzna. Na przeciwnym biegunie sytuują się natomiast mikrotoponimy, a więc nazwy pól, łąk, lasów po opuszczonych, bądź nieistniejących już młynach, jak Krupki, Kumat, Onaczki, Wilginie, Żegunie. Można wyodrębnić jeszcze jedną grupę nazw, a mianowicie onimy, które nazywały w przeszłości niewielkie pola, role, zagony w obrębie osad młyńskich, lub sąsiednich wsi, będące własnością młynarzy, np. Mielechowszczyzna, Puhacowizna.

Jak wynika z analizy przekształceń osadniczo-własnościowych w obrębie poszczególnych osad młyńskich, tego typu procesy wiązały się często ze zmianą nazwy. Jest to jedna z bardziej charakterystycznych cech znamionujących nazewnictwo młynów, która zarazem sytuuje je na pograniczu toponimii i chrematonimii. W dawnym starostwie brańskim kilka młynów (Wysockie, Onacki, Majorowizna, Nełchy, Otapy) zmieniło swe nazwy na przestrzeni wieków, a niektóre nawet dwukrotnie.

To co wyróżnia zebrany zbiór onimów, to zdecydowana przewaga w nim nazw rodowych. Jest to, według wszelkiego prawdopodobieństwa, związane

49 Por. n. os. Sracz, o tej samej podstawie, zob. SEMot 284. 
z dominującym na tym terenie modelem nazewnictwa miejscowego. Większość nazw wsi drobnej szlachty mazowieckiej i podlaskiej oraz wiele wsi starostwa brańskiego (np. Holonki, Jośki, Klichy, Malesze, Szpaki, Świrydy, Zanie), sąsiadujących z osadami młyńskimi, ma właśnie taką postać.

Do grupy nazw dzierżawczych należą takie miana jak Majerowizna, Jarmarkowszczyzna, historyczną nazwa młyna Daszkowszczyzna, oraz nazwy terenowe powiązane z osadami młyńskimi, jak np. Mielechowszczyzna, Puhacowizna, Rybakowszczyzna, Szpakowszczyzna, Wasiukowizna.

Interesującą grupę stanowią nazwy transonimiczne w N. sg. pozbawione wykładników formalnych np. Burkat, Kumat, Onacko, Otap, Puchacz, Solnik, Surojeska, Szczęsny, Wilginia, Wojtkowic(z), Żegunia, Borzymowski, Kiersnowski, Kunicki, Wysocki. Analiza zapisów źródłowych upewnia nas, że na badanym terenie nazwy te nie miały trwałego charakteru, stanowiąc oboczne warianty nazw rodowych. Większość onomastów widzi w nich nazwy dzierżawcze. Na badanym terenie nie był to najwidoczniej popularny model nazewniczy. Za ich nieco sztucznym charakterem, przemawia występowanie tej kategorii onimów w księgach Metryki Koronnej oraz lustracjach, co może wskazywać na oddziaływanie wzorca kancelaryjnego. W księgach grodzkich z tego samego okresu, prowadzonych przez osoby dobrze znające lokalne zwyczaje nazewnicze ich odpowiednikami są nazwy rodowe.

Z przedstawionego wyżej materiału źródłowego wynika, że w tworzeniu nazw młynów i osad młyńskich dawnego starostwa brańskiego stosowany był antropocentryczny model kreacji onimicznej. Jedyną nazwą, nie motywowaną antroponimem, jest dzierżawcza nazwa miejscowa Majorowizna, która odnosi się do rangi, godności, a więc, de facto, wskazuje na osobę za pośrednictwem pełnionej przez nią funkcji. Wszystkie pozostałe miana motywowane są imieniem, przezwiskiem, przydomkiem lub nazwiskiem młynarza bądź dzierżawcy lub posiadacza młyna. W nazwach tych znajduje odbicie zróżnicowanie etniczno-religijne obszaru dawnego starostwa brańskiego. W ich podstawach odnaleźć można antroponimy, występujące zarówno w kręgu chrześcijaństwa wschodniego np. Onaczko, Mielech, jak również te kojarzone z zachodniosłowiańskim kręgiem kulturowym np. Wojciech. Co się zaś tyczy nazw podejrzewanych, na podstawie dotychczasowych badaniach onomastycznych, o pochodzenie bałtyjskie np. Kumat, Torule, Wilginie, Żegunie, trzeba zastanowić się, czy nie należałoby szukać dla mich motywacji w antroponimach słowiańskich. Niewykluczone, że na rezultat badań onomastycznych mogła mieć wpływ w tym przypadku, intrygująca miejscowa legenda o wodzu jaćwieskim Kumacie, który w okolicy Brańska miał stoczyć bitwę z wojskami polskimi, znajdując tu jednocześnie miejsce wiecznego spoczynku. 


\section{Słownik nazw}

Abramiki: Zascianek trzeci, gdzie beli stare sielidbi boiar Spakow ... konczi sie $w$ rzeczke Bronke ... po rzecke abo strumien Lachwiczowke 1560-1563 [PKGE II, s. 374]; Zascianek pusthi na Maleszach na imie Spakowski od rzeczki Lachwicowki de rzeczki Bronki /1565/ 1598 [M 1708-1-82, k. 48]; dobra ... Szpakowsczyzna 1665 [M 1708-1-159, k. 117]; bonorum ... Spakowsczyzna 1665 [M 1708-1-158, k. 233 v.]; Zascianek Szpakowszczyzna nazwany Trzymaia Pawet y Fiedor Abramikowie przy Młynie Mieszkaiacy 1667 [AR XXV 362a, k. 11 v.]; de Villa ... Abrahamiki, de eadem villa ... Abrahamiki 1688 [M 1708-1-188, k. 545]; Młyn Abrahamiki 1716 [KGB 44, k. 378 v.]; Abramiki 1782 [Ks. Ref. 60, k. 21 v.]; Osady Abrahamikow w Buynowie 1782 [Ks. Ref. 58, k. 228 v.]; Wieś Abramiki 1846 [Br III/S/1, k. 40 v.]; Абрамки 1890 [SZ 98].

Burkaty: Mtynarze ... z Burkat 1599 [Ks. Ref. 2, k. 12 v.]; molendini dicti Burkath in Capitaneatu Branscensi et fluuio Liscza sitti 1599 [MK143, k. 195]; Honestos Simonem Joannem Nicolaum et Albertum Burkatom possesores molendini in Capitaneatu Branscen in Fluuio Licha 1651 [M 1708-1-141, k. 835- 835 v.]; Burhati 1650 [M 1708-1-141, k. 439 v.]; in Burkaty 1651 [M 1708-1-141, k. 464 v.]; Mlyn Burkaty nazwany na Rzece Lichczy 1661-1664 [AR XXV 361, k. 6]; Mtyn Burkaty na Rzece Likczy 1667 [AR XXV 362a, k. 4 v.]; Mtyn Burkaty 1674 [ASK I 70, k. 446]; de Burkaty 1681 [M 1708-1-176, k. 237]; de Burgaty 1681 [M 1708-1-176, k. 237 v.]; de Burkaty 1685 [M 1708-1-182, k. 155]; Burkaty Wies 1692 [KGB 52, k. 187 v.]; W Burchatach 1716 [KGB 44, k. 377 v.]; Burkaty 1782 [Ks. Ref. 60, k. 21 v.]; Wieś Burchaty 1846 [Br III/S/1, k. 52 v.]; Бypxambl 1890 [SZ 96]; Burchaty 1921 [SM 29].

Jarmarkowszczyzna: Mlynarze Ziarmarkowczyzny 1599 [Ks. Ref. 2, k. 12 v.]; Molendini dicti Jarmakowcziznam Capitaneatu Branscensi et fluuio Bronka sit 1599 [MK 143, k. 189 v.]; de Jarmakowczizna 1601 [M 1708-1-91, k. 392 v.]; de Jarmarkowsczizna 1601 [M 1708-1-91, k. 36 v.]; Mtyn nazwany Jarmarkowsczyzna na Rzece Bronce 1661-1664 [AR XXV 361, k. 7]; de Jarmakowczyzna 1662 [M 1708-1-153, k. 346]; de Jarmarkowscizna 1663 [M 1708-1-43, k. 455 v.]; de Jarmakowszczyzna 1667 [M 1708-1-45, k. 405 v.]; Młyn Jarmakowsczyzna na Rzece Bronce 1667 [AR XXV 362a, k. 4 v.]; Mtyn Jarmarkowczyzna 1674 [ASK I 70, k. 446]; Jarmakowscizna 1681 [M 1802-1-1, k. 189]; de Jarmakowizna 1689 [M 1708-1-190, k. 222]; de Jarmakowizna 1690 [M 1708-1-57, k. 99 v.]; de Jarmokowsczyzna 1690 [M 1708-1-57, k. 313]; de Jarmakowsczyzna 1690 [M 1708-1-57, k. 315]; Jarmarkowszczyzna 1692 [KGB 52, k. 185]; Jarmar- 
kowszczyzna 1782 [Ks. Ref. 60, k. 21 v.]; Mtyn Jarmarkowszczyzna 1846 [Br III/S/1, k. 36 v.]; Ярмарковщизна 1890 [SZ 98]; Jarmarkowszczyzna 1921 [SM 19].

Krupki: molendinum dictum Krupkowski 1600 [M 1708-1-19, k. 117 v.]; It certa pars agri cum syluis et rubetis riuis et fluuiolo limit suis distincta vulgo nuncupata Krupki ubi apparent circa aggerem antiqua vestigia molendini 1662-1664 [ADS 149, k. 15 v.]; do Krupkow 1679 [M 1708-1-174, k. 623 v.]; młyna na gruncie Krupki w Starostwie Brańskim leżacego ... mlyna niegdy Krupki zwanego 1778 [Ks. Ref. 31, k 129 v.].

Kumat: campo od Kumata 1679 [M 1708-1-174, k. 623 v.]; w Dworze Woytostwa Bra[ńskiego] to jest w Kierznowku pod Kumatem 1784 [KRB, k. 193].

Majorowizna: Młyn Kiersnowski nazwany na Rzece Nurcu 1661-1664 [AR XXV 361, k. 7]; G. Żelski ... Młyn Kierznowo Nazwany Daszkowszczyzna po Panu Woyciechu Kierznowskim Daszkiewiczu 1663 [M 1708-1-43, k. 484]; Mtyn Kiersnowski na Rzece Nurcu ... Tego possesorem natenczas zostaie JmP Jan Zelski Maior JKMsci 1667 [AR XXV 362a, k. 4 v.]; Mtyn Je[g]om[os]ci P. Żelskiego 1674 [ASK I 70, k. 446]; Mtyn Maryowizna 1846 [Br III/S/1, k. 32]; Маіоровизна 1890 [SZ 96]; Majorowizna 1921 [SM 22].

Mielechy: de Mielechi 1608 [M 1708-1-98, k. 690 v.]; Mtyn Mielechy nazwany na Nurcu 1661-1664 [AR XXV 361, k. 5]; Mtyn Mielechy nazwany na Nurcu 1667 [AR XXV 362a, k. 4]; Mtyn Mielechy 1674 [ASK I 70, k. 446]; Mielechy 1675 [Br I/B/1]; in villa Choiewo ... Terrae ... nuncupatam Mielechowska 1679 [M 1708-1-174, k. 638 v.]; Sianożęci osobney między Rzekami Nurcem y Leszczka leżacey Melechowszczyzna zwaney 1782 [Ks. Ref. 58, k. 229].

Nełchy: mlina Niesterowicz 1560-1563 [PKGE II, s. 379]; Mlin na rzece Narczu (!) Jarosza Miskrowicz (!) 1560-1563 [PKGE II, s. 409]; Mtyn Mielechy nazwany na Nurcu 1661-1664 [AR XXV 361, k. 5]; Młyn Nielchy nazwany na Nurcu 1667 [AR XXV 362a, k. 4]; Młynarze Nelchy 1674 [ASK I 70, k. 446 v.]; Mietchi 1675 [M 1708-1-171, k. 302-302 v.]; de Mielchy 1678 [M 1708-1-174, k. 135]; Netchi 1692 [KGB 52, k. 202]; Wies Netchy 1716 [KGB 44, k. 378]; Netchy a teraz Kunicki 1782 [Ks. Ref. 60, k. 21 v.]; Mtynarze Netchi 1846 [Br III/S/1, k. 44].

Onaczki: Mlin uroczisczem Raczkowiczi (!), na rzecze Lichczei ... od sasczianku mlina Boczkowicz 1560-1563 [PKGE II, s. 410, 411]; z Boczkowicz 1599 [Ks. Ref. 2, k. 12 v.]; molendini dicti Bockowic in Capitaneatu Branscensi et fluuio Lichcza siti 1599 [MK143, k. 186]; Mtyn Onaczko nazwany na Lichczy 1661-1664 [AR XXV 361, k. 6]; we Młynie Onaczkach nazwa- 
nem na Rzecze Lysczy w starostwie Branskiem 1666 [M 1708-1-158, k. 448]; Młyn Onacko na Rzece Likczy 1667 [AR XXV 362a, k. 4 v.]; Mtynarze Onacki 1674 [ASK I 70, k. 446 v.]; Molendini Onaczki 1676 M 1708-1-172, k. 13; in molendino dicto Onacki 1678 M 1708-1-174, k. 390; de villa Onaczki 1685 [M 1708-1-182, k. 525 v.]; Mtynarze Onacki Starostwa Branskiego 1692 [KGB 52, k. 189]; Wies Onacki 1716 [KGB 44, k. 378 v.]; Onacki 1782 [Ks. Ref. 60, k. 21 v.]; Wieś Onacki 1846 [Br III/S/1, k. 53]; Оначкu 1890 [SZ 96].

Otapy: Mlin Jana Borzimowskiego na rzecze Nurczu 1560-1563 [PKGE II, s. 406]; molendinum in villa Kierznowo ... Borymowski dictu[m] 1632 [RA Enskilda 8636, k. 140]; Młyn na Rzece Nurcu ... Szczęsny nazwany 1661-1664 [AR XXV 361, k. 5]; Mtynem nazwanym Szczęsne 1667 [AR XXV 362a, k. 4 v.]; molendini Borzimowski 1672 [M 1708-1-49, k. 321]; Sup molendinum Sczesnowski 1672 [M 1708-1-49, k. 321]; Sczesny 1674 [M 1708-1-170, k. 123]; Mtyn Otapow 1674 [ASK I 70, k. 446]; Otapowskie mtynarze 1681 [M 1802-1-1, k. 189 v.]; in molendino dicto Otapy 1691 [M 1708-1-192, k. 192]; Kiersznowo Otapiki 1692 [KGB 52, k. 188]; Otapy 1716 [KGB 44, k. 377 v.]; Mtyn Otapy 1846 [Br III/S/1, k. 32]; Otapy 1921 [SM 22].

Pace: Mtynarze s tych Wtosci z ... Paciewic 1599 [Ks. Ref. 2, k. 12 v.]; de Pacze 1630 [M 1708-1-206, k. 484 v.]; de villa Pacze Capitaneatus Bran 1645 [M 1708-1-137, k. 321 v.]; de Pacze molendinator 1651 [M 1708-1-141, k. 491 v.]; de Pace 1661 [M 1708-1-153, k. 5 v.-6]; Mtyn Pace Nazwany na Nurcu 1661-1664 [AR XXV 361, k. 5]; de Pace 1666 [M 1708-1-158, k. 607]; Młyn Pace nazwany na Nurcu 1667 [AR XXV 362a, k. 4]; de Pace 1668 [M 1708-1-161, k. 420 v.]; sortem suam dictam Pacze seu Obręb Mtynarski 1671 [M 1708-1-168, k. 434]; Mtyn Pacze 1674 [ASK I 70, k. 446]; de uilla Pace 1679 [M 1708-1-174, k. 638-638 v.]; de Pace 1681 [M 1708-1-176, k. 503]; de Pace 1685 [M 1708-1-182, k. 402 v.]; de Villa Pace 1693 [M 1708-1-59, k. 154]; Pace 1782 [Ks. Ref. 60, k. 21 v.]; Mtynarze Pace Starostwa Branskiego 1692 [KGB 52, k. 189]; Wies Pace 1716 [KGB 44, k. 379]; Osada Mtynarska Pace zwana nad Rzeka Nurcem 1782 [Ks. Ref. 58, k. 229]; Wieś Pace 1846 [Br III/S/1, k. 44 v.]; Паub 1890 [SZ 96]; Pace 1921 [SM 22].

Puchacze: de villa Puhacze 1618 [M 1708-1-31, k. 635]; de Puchacze 1651 [M 1708-1-141, k. 637]; Mtyn Puhacz 1661-1664 [AR XXV 361, k. 7]; spuhacow 1662 [M 1708-1-42, k. 321 v.]; de Villa Puhacze 1662 [M 1708-1-153, k. 346]; de Puhace 1663 [M 1708-1-43, k. 479]; Puhacowizna Wasiukowizna 1665 [M 1708-1-158, k. 233 v.]; de Puchacze 1667 [M 1708-1-45, k. 155 v.]; Mtyn Puhacz nazwany na Rzece Bronce 1667 
[AR XXV 362a, k. 4 v.]; de Villa Puchacze 1672 [M 1708-1-49, k. 309 v.]; in Puhacze 1683 [M 1708-1-52, k. 206]; de Puhacze 1690 [M 1708-1-57, k. 263 v.]; Puhacze 1692 [KGB 52, k. 202]; Mtyn Puhacze 1716 [KGB 44, k. 378 v.]; Puchacze 1782 [Ks. Ref. 60, k. 21 v.]; osadzie mtynarskiey Puchaczowskiey 1782 [Ks. Ref. 58, k. 227 v.]; Wieś Puhacze 1846 [Br III/S/1, k. 40]; Пугачи 1890 [SZ 98].

Solniki: Mlin Solniki 1560-1563 [PKGE II, s. 411]; Mtynarze s tych Wtosci z ... Solnik 1599 [Ks. Ref. 2, k. 12 v.]; molendini dicti Solnik in Capitaneatu Branscensi et fluuio Lichcza siti 1599 [MK143, k. 196-196 v.]; de Molendino Solniky 1599 [M 1708-1-18, k. 193 v.]; de Solinki 1601 [M 1708-1-91, k. 361]; de Solniki 1606 [M 1708-1-96, k. 264 v.]; de Solniki 1607 [M 1708-1-98, k. 188 v.]; de Solniki 1645 [M 1708-1-137, k. 49]; de Solniki 1648 [M 1708-1-37, k. 382]; de Solniki 1655 [M 1708-1-39, k. 231]; Mtyn Solniki nazwany na Rzece Lichczy 1661-1664 [AR XXV 361, k. 6]; Mtyn Solnicki na Rzece Likczy 1667 [AR XXV 362a, k. 4 v.]; de Solniki 1670 [M 1708-1-168, k. 294]; de Solniki 1672 [M 1708-1-169, k. 159 v.]; Wies Solniki 1674 [ASK I 70, k. 446 v.]; in villa Smolniki (!) [1682 M 1708-1-177, k. 215]; de Solniki 1684 [M 1708-1-53, k. 30]; de Solniki her[e]di 1685 [M 1708-1-182, k. 245 v.]; de villa Młynarze Solniki 1688 [M 1708-1-188, k. 199]; Mtynarze Solniki 1692 [KGB 52, k. 187]; Solniki 1716 [KGB 44, k. 379]; Solniki 1782 [Ks. Ref. 60, k. 21 v.]; Wieś Solniki 1846 [Br III/S/1, k. 53 v.]; Сольники 1890 [SZ 96]; Solniki 1921 [SM 30].

Torule: Mlin na rzecze Czarnei, uroczisczem Turulie ... mlina Turule 1560-1563 [PKGE II, s. 410]; de Turule 1661 [M 1708-1-153, k. 76 v.]; Mtyn Tutule nazwany na Rzece Czarney 1661-1664 [AR XXV 361, k. 6]; de Turule 1666 [M 1708-1-158, k. 636]; Mtyn Turule na Czarney Rzece 1667 [AR XXV 362a, k. 4 v.]; Młynarze Turulle 1674 [ASK I 70, k. 446]; de Turule 1675 [M 1708-1-171, k. 317]; de Turule 1679 [M 1708-1-174, k. 505-505 v.]; Turule Wies 1692 [KGB 52, k. 187]; Wies Turule 1716 [KGB 44, k. 379]; Turule 1782 [Ks. Ref. 60, k. 21 v.]; Wieś Turule 1846 [Br III/S/1, k. 56]; Турули 1890 [SZ 96]; Torule 1921 [SM 30].

Wilginie: Mlin na rzecze Czarnei, uroczisczem Wilkina 1560-1563 [PKGE II, s. 410]; Zwilkim 1599 [Ks. Ref. 2, k. 12 v.]; molendini dicti Wolkinia in Capitaneatu Branscensi et fluuio Czarna 1599 [MK143, k. 196 v.]; Molendinum in fluuio Czarna situ[m] ad Cap[ita]neatum Branscen pertinens Vilginie dictu/m] 1635 [MK181, k. 122]; de Vilga 1650 [M 1708-1-141, k. 306]; de Wilkinie 1661 [M 1708-1-153, k. 27 v.]; Mtyn Wilkinie na Czarney Rzece 1661-1664 [AR XXV 361, k. 6]; Mtyn Wilkinie na Czarney Rzece 1667 [AR XXV 362a, k. 4 v.]; de Wilginie 1672 
[M 1708-1-49, k. 74]; Młyn Wilginie 1674 [ASK I 70, k. 446]; de Wilkinie 1675 [M 1708-1-171, k. 317]; de Wilginie 1676 [M 1708-1-172, k. 111 v.]; Wilginie Mtyn 1692 [KGB 52, k. 187 v.]; Wies Wilginie 1716 [KGB 44, k. 378 v.]; Wilginie 1782 [Ks. Ref. 60, k. 21 v.]; Wieś Wilginie 1846 [Br III/S/1, k. 55 v.].

Wojtki: z Woitkowic 1599 [Ks. Ref. 2, k. 12 v.]; molendini dicti Woitkowic in Capitaneatu Branscen et fluuio Czarna siti 1599 [MK143, k. 199 v.-200]; de molendino Woytkowicze nuncupato 1601 [M 1708-1-91, k. 442 v.]; de villa Woitkowicze 1617 [M 1708-1-31, k. 160 v.]; de villa Woytkoice Mtynarze 1655 [M 1708-1-39, k. 231]; Mtyn Woytkowicz 1661-1664 [AR XXV 361, k. 6]; de Woytkowice 1662 [M 1708-1-153, k. 360]; de Woytkowice 1663 [M 1708-1-43, k. 273]; de villa Woytkowicze Mtynarze 1664 [M 1708-1-156, k. 448]; Młyn Woytkowicze na Rzece Czarney 1667 [AR XXV 362a, k. 4 v.]; Mtynarze Woytkowicze 1674 [ASK I 70, k. 446]; de villa Woytkowicze Mlynarze 1688 [M 1708-1-188, k. 199]; Woytkowice Wies 1692 [KGB 52, k. 187]; Woytkowicze 1716 [KGB 44, k. 379]; Woytki 1782 [Ks. Ref. 60, k. 21 v.]; Wieś Woytki 1846 [Br III/S/1, k. 54 v.]; Boümкu 1890 [SZ 96]; Wojtki 1921 [SM 30].

Wysockie: Mlin Suroieska. Mlinarze Jurek Sacz, Simek Smoieskowicz ... na rzeczce Lichczei 1560-1563 [PKGE II, s. 409, 410]; Młyn Wysocki nazwany na Rzece Lichczy 1661-1664 [AR XXV 361, k. 6]; Młyn Wysocki na Rzece Likczy 1667 [AR XXV 362a, k. 4 v.]; Mtynarze Wysockie 1674 [ASK I 70, k. 446]; de Wysockie 1681 [M1708-1-176, k. 503]; de Wysockie 1691 [M 1708-1-192, k. 70]; Wysockie Wies 1692 [KGB 52, k. 188]; W Wysockich 1716 [KGB 44, k. 377 v.]; Wysockie 1782 [Ks. Ref. 60, k. 21 v.]; Osady Suroiewska a przedtym Wysocki zwaney 1782 [Ks. Ref. 58, k. 425 v.].

Żegunie: od zasczianku mlinarskiego Zegunie Srakowie ... Mlin na rzecze Lichczi, uroczisczem Zeguniowie Srakowie 1560-1563 [PKGE II, s. 411]; Mtynarze s tych Włosci z ... Żegonia 1599 [Ks. Ref. 2, k. 12 v.]; molendini dicti Żeguina in Capitaneatu Branscen et fluuio Lichcza sitti 1599 [MK143, k. 199-199 v.]; de Żegunie 1607 [M 1708-1-98, k. 188 v.]; de Żegunie 1645 [M 1708-1-137, k. 208 v.]; de Żegunie 1655 [M 1708-1-39, k. 410 v.]; Młyn Zegunie na Rzece Lichczy 1661-1664 [AR XXV 361, k. 6]; Mtyn Zegunie na Rzece Likczy 1667 [AR XXV 362a, k. 4 v.]; Młynarze Żegunie 1674 [ASK I 70, k. 446 v.]; de Zegunie 1684 [M 1708-1-53, k. 29 v.]; Mtynarze Żegunie Starostwa Brans[kiego] 1692 [KGB 52, k. 189]; Zegunie 1716 [KGB 44, k. 379]; Zegunie 1782 [Ks. Ref. 60, k. 21 v.]; Wieś Żegunie 1846 [Br III/S/1, k. 53 v.]. 


\section{Źródła}

AVAK XIV Inventarz y lidzba skarbowa starostw Branskiego y Saraskiego 1558 [w:] Акты издаваемые Виленскою Археографическою Комиссею, Вильна 1888 , s. $24-45$.

PKGE II Уволочное измерение городов Брянска и Саража с принадлежашими к ним волостями составленное Девялтовским-Скочком в 1560-1563-м г. [w:] Писцовая книга Гродненской экономии с прибавлениями, II, Вильна 1882.

SM Skorowidz miejscowości Rzeczypospolitej Polskiej, t. V, Województwo białostockie, Warszawa 1924.

SZ Список землевладений в Гродненской губернии, сост. П. Диков, Гродна 1890.

AGAD Warszawa

AR XXV 361 Lustracja starostwa brańskiego z l. 1661-1664

AR XXV 362a Inwentarz włości starostwa brańskiego z 1667 r.

ASK I 70 Rejestr poborowy pow. brańskiego z $1674 \mathrm{r}$.

Księgi grodzkie brańskie: KGB 44 z l. 1670-1726; KGB 52 z 1692 i 1712 r.

Księgi Sądu Referendarskiego: Ks. Ref. 2 z l. 1581, 1599-1601; Ks. Ref. 31 z l. $1777-1780$; Ks. Ref. 58 z l. 1780-1783; Ks. Ref. 60 z l. 1781-1788.

Księgi wpisów Metryki Koronnej: MK 143 z 1599 r.; MK 181 z l. 1629, 1631, $1634-1637$.

AD Drohiczyn

Br I/B/1 Księga chrztów par. Brańsk z l. 1644-1701.

Br III/S/1 Księga spisu parafialnego par. Brańsk z 1846 r.

Bk I/B/4 Księga chrztów par. Boćki z l. 1748-1762.

KRB Księga radziecka (miejska) brańska z l. 1779-1789.

AD Siedlce

ADS 149 Acta visitationis generalis ecclesiarum palatinatus Podlachiae et Brestensis z l. 1662-1664.

НГАБ Мінск

Księgi grodzkie brańskie: M 1708-1-4 z l. 1562-1563; M 1708-1-18 z r. 1599; M 1708-1-19 z l. 1600-1601; M 1708-1-37 z l. 1648-1649; M 1708-1-31 z l. 1617-1618; M 1708-1-39 z 1655 r.; M 1708-1-42 z l. 1661-1662; M 1708-1-43 z 1663 r.; M 1708-1-45 z 1667 r.; M 1708-1-49 z l. 1672-1673; M 1708-1-52 z 1683 r.; M 1708-1-53 z 1684 r.; M 1708-1-57 z 1690 r.; M 1708-1-59 z 1693 r.; M 1708-1-82 z 1598 r.; M 1708-1-91 z 1601 r.; M 1708-1-96 z l. 1605-1606; M 1708-1-98 z l. 1607-1608; M 1708-1-137 z 1645 r.; M 1708-1-141 z l. 1650-1651; M 1708-1-153 z l. 1661-1662; M 1708-1-156 z 1664 r.; M 1708-1-158 z l. 1665-1666; M 1708-1-159 z 1665 r.; M 1708-1-161 z l. 1667-1668; M 1708-1-168 z l. 1670-1671; M 1708-1-169 z l. 1672-1673; M 1708-1-170 z 1674 r.; M 1708-1-171 z 1675 r.; M $1708-1-172$ z 1676 r.; M 1708-1-174 z l. 1678-1679; M 1708-1-177 z 1682 r.; M 1708-1-182 z 1685 r.; M 1708-1-188 z 1688 r.; M 1708-1-190 z 1689 r.; M 1708-1-192 z 1691 r.; M 1708-1-206 z 1630 r. 
Księga miejska brańska M 1802-1-1 z l. 1676-1681

RA Enskilda 8636, Repozytorium Cyfrowe Poloników, [online], http://www.repcyfr.pl/dlibra/docmetadata?id $=2561 \&$ from $=\&$ dirids $=1 \& v e r \_i d=$ 2586\&lp=11\&QI=!6CEF3C76C637897C3974EB25D255D190-18, [11.05.2015]

\section{Literatura}

Gołębiowska T., 1969, Nazwy polskich mlynów, „Onomastica” XIV, s. 81-120.

Kondratiuk M., 1974, Nazwy miejscowe poludniowo-wschodniej Białostocczyzny, Wrocław.

Kondratiuk M., 1985, Elementy battyckie $w$ toponimii $i$ mikrotoponimii regionu białostockiego, Wrocław.

Malec M., 1994, Imiona chrześcijańskie w średniowiecznej Polsce, Kraków.

SEMot Stownik etymologiczno-motywacyjny staropolskich nazw osobowych, cz. 1. Odapelatywne nazwy osobowe, opr. A. Cieślikowa, J.Szymowa, K. Rymut, Kraków 2000, s. 243.

SHNOB - Z. Abramowicz, L. Citko, L. Dacewicz, 1997-1998, Stownik historycznych nazw osobowych Białostocczyzny (XV-XVII w.), t. I-II, Białystok.

SNT Stownik nazw terenowych pótnocno-wschodniej Polski, 1992, red. N. Barszczewska, J. Głuszkowska, T. Jasińska, E. Smułkowa.

Tichoniuk B., 1988, Antroponimia poludniowej Białostocczyzny, Opole.

Tichoniuk B., 2000, Imiona $i$ ich formy na pograniczu polsko-biatoruskim od XVI wieku do roku 1839, Zielona Góra.

UN Urzędowe nazwy miejscowości i obiektów fizjograficznych, 152, Powiat bielski, województwo białostockie, 1972.

Wiśniewski J., 1970, Nazwy młynów w Polsce, „Kwartalnik Historii Kultury Materialnej", XVIII, nr 3, s. 449-455.

WUN Wykaz urzędowych nazw i ich części ogłoszony rozporzadzeniem Ministra Administracji i Cyfryzacji z 13.12.2012, plik PDF, [online], ksng.guik.gov.pl/ urzedowe_nazwy_miejscowosci.php [9.05.2015].

Złotkowski P., 2014, O pochodzeniu nazwy uroczyska Kumat pod Brańskiem. Czyżby koniec legendy?, „Studia Białorutenistyczne”, nr 8, s. 237-250.

\section{Inne skróty}

gr. - grecki, cerk. - cerkiewny, wsł. - wschodniosłowiański, im. - imię, ap. - apelatyw, n. os. - nazwa osobowa, germ. - germański, hebr. - hebrajski, słow. - słowiański, bałt. - bałtycki. 


\title{
THE MILL NAMES AND MILL VILLAGE NAMES OF THE FORMER BRANSK STAROSTY
}

\author{
S U M M A R Y
}

The purpose of this paper is to examine of the mill names and mill village names in the Bransk region of the Podlachia province from 16th to the 21 th century. It was discovered that the amount of the mills in this territory has decreased over several centuries. A few mills disappeared, some of the other changed their names. The study area is dominated by toponyms related to personal names. These village names are created from the forenames, nicknames and surnames of millers. There are a good number of toponyms of West and East Slavic origin in the area, while Baltic origin are few. 